\title{
МЕДИЧНЕ ЗАБЕЗПЕЧЕННЯ ЗБРОЙНИХ СИЛ УКРАЇНИ: ДОСВІД, ЗДОБУТКИ, ПЕРСПЕКТИВИ
}

\author{
А.М. Галушка' ${ }^{1}$ В.О. Жаховський ${ }^{2}$ В.Г. Лівінський ${ }^{2}$ \\ ${ }^{1}$ Командування Медичних сил Збройних Сил Украӥни, м. Київ, Україна \\ 2Українська військово-медична академія, м. Київ, Україна
}

\begin{abstract}
Мета роботи: узагальнення досвіду медичного забезпечення Збройних Сил (ЗС) України під час здійснення заходів із забезпечення національної безпеки і оборони, відсічі та стримування збройної агресії Російської Федерації та визначення перспектив розвитку Медичних сил Збройних Сил України.

Матеріали та методи. Використані нормативно-правові акти, керівні документи, інформаційнодовідкові матеріали, монографії та наукові статті у відкритих виданнях щодо медичного забезпечення ЗС України. Об'єкт дослідження - система медичного забезпечення ЗС України. Предмет дослідження Медичні сили Збройних Сил України. Методи дослідження: бібліографічний, аналітичний, системного підходу, узагальнення, прогностичний.

Результати. Узагальнено практичний досвід медичного забезпечення ЗС України та надання медичної допомоги пораненим, ураженим, травмованим і хворим військовослужбовцям під час здійснення заходів із забезпечення національної безпеки і оборони, відсічі та стримування збройної агресії Російської Федерації проти України. Висвітлено розвиток нормативно-правового врегулювання функціонування системи охорони здоров'я військовослужбовців та медичного забезпечення військ. Критично оцінено здобутки щодо розвитку системи медичного забезпечення ЗС України, зокрема вдосконалення організаційно-штатної структури медичних підрозділів військових частин і військово-медичних закладів, формування системи управління Медичними силами. Сформульовано засади єдиного медичного простору держави та визначено перспективи розвитку Медичних сил ЗС України.

Висновки. Вивчення, аналіз та узагальнення досвіду медичного забезпечення ЗС України під час АТО/OОС стали основою формування сучасної системи медичного забезпечення військ. Найбільш важливим здобутком Медичних сил є розроблення і впровадження на державному рівні сучасної функціональноорганізаційної моделі медичного забезпечення ЗС України та інших військових формувань під час дії особливого періоду, надзвичайного стану та інших кризових ситуацій для забезпечення національної безпеки і оборони держави. Спроможні Медичні сили та, як результат, надійне медичне забезпечення військ в умовах бойових дій є вагомим внеском у забезпечення національної безпеки та оборони держави через підвищення боєготовності і боєздатності ЗС України та інших складових Сил оборони.
\end{abstract}

Ключові слова: система медичного забезпечення ЗС України, медична допомога, Медичні сили Збройних Сил України.

Вступ. Вже більше семи років на території України в форматі антитерористичної операції та операції Об'єднаних сил (АТО/ООС) тривають бойові дії, які супроводжуються великою кількістю загиблих i поранених як серед військовослужбовців, так і серед цивільного населення. За часи цієї гібридної війни, а фактично збройної агресії Російської Федерації проти нашої держави, всі складові Сил оборони, у тому числі Збройні Сили (3С) України, набули практичного досвіду ведення бойових дій і пройшли шлях удосконалення, розвитку та нарощування бойових спроможностей, який визначався відповідними законодавчими і нормативноправовими актами України.

Так, у 2015 році Указом Президента України затверджено нову редакцію Воєнної доктрини України, якою встановлено, що головна роль у забезпеченні воєнної безпеки, державного суверенітету і територіальної цілісності держави належить ЗС України, розвиток яких здійснюватиметься за західними стандартами 3 метою досягнення сумісності зі збройними силами держав-членів НАТО, а одним із напрямів їх реформування та розвитку $є$ модернізація системи медичного забезпечення військ із максимальною інтеграцією її з цивільною системою охорони здоров'я [1].

У Концепції розвитку сектору безпеки і оборони України сформульовано основну мету та завдання розвитку сектору безпеки $\mathrm{i}$ оборони, а саме формування та підтримання спроможностей, що дадуть змогу гарантовано забезпечити адекватне і гнучке реагування на весь спектр загроз національній безпеці України, раціонально використовуючи наявні у державі можливості та ресурси [2]. Концепцією також визначено пріоритети розвитку 3С України, у тому числі їх системи 
медичного забезпечення, а саме: розвиток iㅣ функціональної та організаційної структури, зокрема польової медицини; удосконалення системи підготовки та перепідготовки військово-медичних кадрів; психологічну підтримку військовослужбовців; координацію цивільної та військової систем охорони здоров'я; удосконалення системи управління військово-медичною службою; поглиблення міжнародного співробітництва тощо.

За результатами проведеного оборонного огляду указом Президента України затверджено Стратегічний оборонний бюлетень України, в якому визначено мету і стратегічні цілі оборонної реформи, деталізовано завдання щодо реформування i розвитку 3С України та встановлено оперативну ціль для розвитку системи військової охорони здоров'я - це побудова системи медичного забезпечення для надання належної медичної підтримки всім завданням Сил оборони [3].

Наведеними доктринальними документами визначено, що основою національної безпеки та оборони держави $€$ боєготові та боєздатні ЗС України. Імовірність повномасштабної збройної агресії проти України вимагає завчасного формування загальнодержавної системи охорони здоров'я військовослужбовців, основу якої становитиме сучасна ефективна та спроможна система медичного забезпечення військ в умовах бойових дій.

Стратегією національної безпеки України, яку затверджено у вересні 2020 року визначено, що людина, її життя і здоров'я, честь і гідність, недоторканність і безпека $\epsilon$ найвищою соціальною цінністю в Україні [4].

Із розвитком військових формувань, що здійснювався у відповідності до цих нормативно-правових актів, дістали свого розвитку їх військово-медичні служби. Науковцями Медичних сил 3С України (Білий В.Я., Верба А.В., Хоменко І.П. та інші, у тому числі автори цієї статті) проведено фундаментальні дослідження організації та стану медичного забезпечення 3С України в умовах бойових дій під час ATO/OOC, а також здійснено глибокий аналіз та узагальнення набутого досвіду, який систематизовано та викладено в дисертаційних дослідженнях, монографіях і численних наукових публікаціях $[5,6,7]$. Проаналізовано історичні аспекти розвитку системи медичного забезпечення військ, стан і проблеми медичного забезпечення $3 \mathrm{C}$ України на початку та в різні періоди АTO/OOC, розкрито причини, що до них призвели, а також запропоновано шляхи ї вирішення. Проведено детальний аналіз системи медичного забезпечення ЗС України по роках та за всіма елементами. Досліджено величину та структуру безповоротних і санітарних втрат військ, порядок організації та надання медичної допомоги, проведення медичної евакуації поранених, травмованих, уражених і хворих військовослужбовців починаючи від поля бою та на всіх рівнях медичного забезпечення, a також організацію i проведення медичної та медико-психологічної реабілітації. Висвітлено комплекс санітарногігієнічних i протиепідемічних заходів, організацію, порядок та обсяги медичного постачання, роль і вклад військово-медичної освіти i науки в медичне забезпечення ЗС України. Не припускаючись до повторення проведених досліджень автори вважають за необхідне стисло підсумувати набутий досвід і здобутки Медичних сил $3 \mathrm{C}$ України за вказаний період та окреслити перспективи і напрями їх подальшого розвитку.

Мета роботи. Узагальнення досвіду медичного забезпечення 3С України під час здійснення заходів із забезпечення національної безпеки і оборони, відсічі та стримування збройної агресії Російської Федерації та визначення перспектив розвитку Медичних сил 3С України.

Матеріали та методи. Використані нормативно-правові акти, керівні документи, інформаційно-довідкові матеріали, монографії та наукові статті у відкритих виданнях щодо медичного забезпечення 3С України. Методи дослідження: бібліографічний, аналітичний, системного підходу, узагальнення, прогностичний.

Результати та їх обговорення. Одним із основних здобутків у розвитку військової медицини в Україні стало формування нормативно-правової бази функціонування системи охорони здоров'я військовослужбовців і медичного забезпечення ЗС України та інших військових формувань в мирний час і в умовах особливого періоду, розробленої з урахуванням положень доктринальних документів НАТО щодо медичного забезпечення військ. Наукові розробки і теоретичні напрацювання впроваджено шляхом опрацювання та затвердження встановленим порядком нормативно-правових актів Кабінету Міністрів України, керівних документів 
Міністерства оборони (М0) України, Міністерства охорони здоров'я (М03) України та Генерального штабу (ГШ) ЗС України.

Основоположним документом військової медицини на державному рівні $\epsilon$ Воєнно-медична доктрина України (Доктрина) - всеохоплюючий документ, який стосується всіх структур держави, враховує положення законодавства України з питань охорони здоров'я, національної безпеки i оборони держави, Воєнної доктрини України та служить основою для розроблення нормативно-правових актів нижчого рівня 3 питань охорони здоров'я військовослужбовців і медичного забезпечення військ [8]. Доктрина визначає мету, принципи, організаційні засади системи охорони здоров'я військовослужбовців, повноваження та відповідальність за їі реалізацію, фінансове та ресурсне забезпечення, наукове супроводження військової охорони здоров'я, вирішення проблем військової медицини, а головне - відповідальність держави та органів виконавчої влади за розвиток системи охорони здоров'я військовослужбовців i забезпечення її спроможностей у воєнний час.

3 урахуванням вимог Доктрини, а також положень доктринальних документів збройних сил держав-членів НАТО з питань медичного забезпечення військ, у МО України та 3С України опрацьовано низку нормативноправових актів і керівних документів, зокрема: розпорядження Кабінету Міністрів України «Деякі питання медичного забезпечення військовослужбовців, осіб рядового і начальницького складу та поліцейських, які беруть участь в антитерористичній операції та здійсненні заходів із забезпечення національної безпеки i оборони, відсічі i стримування збройної агресії Російської Федерації у Донецькій та Луганській областях»; спільний наказ МО України та M03 України «Про визначення механізму надання вторинної (спеціалізованої) i третинної (високоспеціалізованої) медичної допомоги військовослужбовцям, які беруть участь в антитерористичній операції та здійсненні заходів із забезпечення національної безпеки і оборони, відсічі і стримування збройної агресії Російської Федерації та/або в умовах запровадження воєнного чи надзвичайного стану»; Доктрину медичного забезпечення Збройних Сил України; Керівництво з медичної евакуації у Збройних Силах України; Настанову 3 медичного забезпечення Збройних Сил
України на особливий період; Доктрину «Медичні сили Збройних Сил України» тощо $[9,10,11,12,13,14]$.

Цими документами визначено основи побудови системи охорони здоров'я військовослужбовців i медичного забезпечення 3С України та інших військових формувань у мирний час та в умовах особливого періоду, а також, що $\epsilon$ найголовнішим, опрацьовано засади єдиного медичного простору держави шляхом інтеграції систем військової та цивільної охорони здоров'я, що об'єднує всі медичні ресурси держави спільним управлінням i визначеними механізмами фінансування та забезпечує доступність, якість і ефективність усіх видів медичної допомоги всім громадянам України, у тому числі військовослужбовцям.

Запропоновано механізми формування єдиного медичного простору, розроблено нові ресурсозберігаючі методичні підходи щодо порядку залучення цивільних закладів охорони здоров'я для медичного забезпечення військ Сил оборони на особливий період, які забезпечують мінімізацію негативного впливу на стан охорони здоров'я цивільного населення в адміністративно-територіальних одиницях i не потребують утримання у мирний час значних запасів матеріальнотехнічних засобів, медичного майна та обладнання для створення в особливий період нових військово-медичних формувань або перепрофілізації існуючих цивільних закладів охорони здоров'я [15].

Колишні підходи та напрацювання щодо формування на особливий період Територіальних госпітальних баз (ТерГБ) М03 України за рахунок цивільних закладів охорони здоров'я під час АТО/ООС виявилися нереалізованими, так як потребували значних матеріальних і фінансових ресурсів.

Водночас нові принципи та методичні підходи щодо формування Тимчасових функціональних об'єднань цивільних закладів охорони здоров'я для надання медичної допомоги пораненим, ураженим, травмованим i хворим військовослужбовцям, запровадження новаторського підходу до формування сучасних засад єдиного медичного простору держави забезпечили відчутний економічний ефект, так як відпала необхідність в утриманні у мирний час значних запасів матеріально-технічних засобів, медичного майна та обладнання для створення в особливий період нових військово-медичних формувань 
(117,3 млн. грн. лише для витратного медичного майна, за даними М03 України) або перепрофілізації існуючих цивільних закладів охорони здоров'я для формування ТерГБ M03 України (2 520 млн. грн., за Матеріалами засідання «круглого столу» Комітету Верховної Ради України з питань охорони здоров'я «Готовність системи охорони здоров'я до роботи та міжвідомчої взаємодії в умовах воєнного стану» 10 грудня 2018 року), що у 3 рази перевищує витрати бюджетних коштів при застосуванні запропонованої моделі залучення цивільних закладів охорони здоров'я для надання в особливий період медичної допомоги пораненим, ураженим, травмованим і хворим військовослужбовцям. Відсутність необхідності проведення відмобілізування Польових центрів медичного забезпечення та їх бойового злагодження дозволить уникнути видатків на їх проведення (573,1 млн. грн., за розрахунками Командування Медичних сил ЗС України).

Окрім теоретичних напрацювань та формування нормативно-правової бази діяльності Медичних сил 3С України, за часи проведення АТО/OОС, залежно від характеру застосування ЗС України, проводилося удосконалення організаційно-штатної структури медичних підрозділів військових частин і військово-медичних закладів, впроваджувалися сучасні стандарти медичної допомоги (медичні стандарти) та військовомедичні стандарти, нові методики надання медичної допомоги, лікування, медичної i медико-психологічної реабілітації поранених, уражених, травмованих i хворих військовослужбовців, проводилося забезпечення Медичних сил виробами медичного призначення, сучасним комплектно-табельним оснащенням, у тому числі індивідуальними засобами медичного захисту, засобами медичної та аеромедичної евакуації, спеціальною медичною технікою, вдосконалювався процес підготовки медичного персоналу [7].

3 метою покращення медичного забезпечення військ удосконалено організаційно-штатну структуру медичної служби бригади, введено посади бойових медиків взводів і старших бойових медиків рот, затверджено нові організаційно-штатні структури медичних пунктів батальйонів і медичних рот бригад, проте вони досі не впроваджені в системі лікувальноевакуаційних заходів під час бойових дій в умовах 00С. За цей час збільшено ліжкову місткість ряду військових госпіталів, сформовано Військово-медичний клінічний центр (ВМКЦ) Східного регіону (м. Дніпро) та військовий госпіталь (ВГ) у м. Маріуполь, дві поліклініки (з денним стаціонаром) (м. Запоріжжя, м. Старокостянтинів) переформовано у 100- та 150-ліжкові військові госпіталі, у ВМКЦ створено нові або ж підсилено існуючі реабілітаційні відділення, збільшено штатну ліжкову місткість клінік і відділень психіатрії, введено психіатричні кабінети з лікарем психіатром і психологом, при Національному військово-медичному клінічному центрі «Головний військовомедичний клінічний госпіталь» сформовано ще один військовий мобільний госпіталь (ВМГ) [7].

Також удосконалено організаційноштатну структуру ВМГ, який на цей час $\epsilon$ передовим і основним етапом надання ранньої хірургічної допомоги пораненим, а саме: введено до штату евакуаційне відділення, відділення (підсилення медичних підрозділів для військової ланки), пересувний рентгенівський та пересувний стоматологічний кабінети, а також кабінет психологічної допомоги. До складу відділення медичного постачання введено групу медичного постачання (пересувну). Крім того, до штату ВМГ додатково введено санітарну та спеціальну техніку, у тому числі реанімобілі.

За результатами проведених організаційних заходів вдалося збільшити штатну чисельність медичної служби військових частин та покращити i укомплектованість особовим складом, проте питання поліпшення ефективності їх діяльності та якості надання медичної допомоги на рівні військової ланки медичної служби і нині залишаються актуальними.

У рамках трансформації системи управління 3С України на стратегічному рівні, формування структури МО України, ГШ 3С України та командувань видів (родів, військ, сил) у відповідності до доктринальних документів НАТО 5 лютого 2020 року сформовано Командування Медичних сил Збройних Сил України (Командування Медичних сил), яке стало правонаступником Головного військово-медичного управління та єдиним органом управління медичним забезпеченням у ЗС України на стратегічному рівні 3 підпорядкуванням Головнокомандувачу Збройних Сил України [16]. 
Командування Медичних сил є органом військового управління та призначене для організації медичного забезпечення 3С України у мирний час та особливий період, управління медичною службою ЗС України, формування та забезпечення реалізації державної політики в галузі охорони здоров'я військовослужбовців, членів їх сімей, військовозобов'язаних та резервістів, які призвані на навчальні (або перевірочні) та спеціальні збори, ветеранів військової служби, ветеранів війни та інших категорій громадян, визначених законодавством України.

Враховуючи практичний досвід медичного забезпечення військ і надання медичної допомоги пораненим, ураженим, травмованим і хворим військовослужбовцям під час АТО/ООС сформовано та впроваджено сучасну систему лікувально-евакуаційних заходів (ЛЕЗ) - систему етапного лікування, як основу медичного забезпечення військ в особливий період, яка включає чотири рівні медичного забезпечення, що відповідає потребам 3С України та положенням доктринальних документів 3 медичного забезпечення збройних сил держав-членів HATO [17].

В рамках системи ЛЕЗ застосовано сучасні підходи до проведення медичної та аеромедичної евакуації, вперше використано залізничний транспорт для проведення тактичної та стратегічної медичної евакуації, завдяки чому всі ВМКЦ і стаціонарні ВГ залучені до надання медичної допомоги постраждалим, в яких, 3 урахуванням етапності, за час АТО/ООС проліковано більше 150 тисяч військовослужбовців - учасників АТО/OOC [7].

Удосконалено надання хірургічної допомоги пораненим шляхом запровадження рівневого підходу в організації надання хірургічної допомоги у відповідності до рівнів медичного забезпечення згідно положень доктринальних документів 3 медичного забезпечення збройних сил держав-членів НАTO, а етапне надання хірургічної допомоги організовано за принципом «Damage Control Surgery».

Завдяки формуванню лікарськосестринських бригад, як загальнолікарських, так і хірургічного профілю, для підсилення в районах проведення АТО/ООС медичних підрозділів батальйонів і бригад, ВМГ, а також цивільних закладів охорони здоров'я, що розташовані в районах, наближених до бойових дій та залучаються для надання медичної допомоги військовослужбовцям, вдалося наблизити кваліфіковану та спеціалізовану медичну допомогу до поранених і забезпечити дотримання принципу своєчасності у наданні медичної допомоги $10-1-2$.

Клінічними досягненнями стало розроблення та впровадження в практику медичного забезпечення військ нових технологій і методик надання своєчасної та якісної медичної допомоги, у тому числі спеціалізованої та високоспеціалізованої, а також проведення медичної та медикопсихологічної реабілітації військовослужбовцям з бойовою хірургічною і терапевтичною патологією, що забезпечило зниження смертності та підвищення виживаємості поранених, зменшення частоти ускладнень, скорочення термінів лікування та прискорило повернення їх до строю. Так, після закінчення стаціонарного лікування близько $65 \%$ поранених, уражених, травмованих i хворих учасників АТО/ООС одразу поверталися до військових частин, ще 17-18 \% надавалася відпустка за хворобою та близько 14-16 \% направлялися на медичну реабілітацію до військових закладів охорони здоров'я [7].

Наведені показники результатів лікувально-діагностичної роботи свідчать про iii значну медичну, соціальну та економічну ефективність. Соціальний ефект полягає в тому, що значно збільшилася частка військовослужбовців, завершивших лікування без зміни категорії придатності та зменшилася кількість осіб, які потребують відпусток за станом здоров'я або встановлення інвалідності.

Економічного ефекту досягнуто завдяки скороченню на 10-15 \% термінів лікування, медичної та медико-психологічної реабілітації поранених, уражених травмованих і хворих військовослужбовців, що призвело до зменшення видатків на їх проведення (до 11 млн. грн. щорічно за час АТО/ООС, розрахунки Командування Медичних сил Збройних Сил України), а також на проведення тривалої соціальної реабілітації. Зниження рівня інвалідизації військовослужбовців на 8$10 \%$ сприяло зменшенню видатків державного бюджету на виплати по інвалідності (близько 50 млн. грн. щорічно за час АТО/OOC).

Вагомим досягненням також стало розроблення напрямів та шляхів ресурсного забезпечення Медичних сил. 3 метою 
забезпечення своєчасності та повноти надання медичної допомоги пораненим на полі бою опрацьовано новий склад аптечки медичної загальновійськової індивідуальної (AM3I), розроблено нові комплекти для надання першої медичної (домедичної) допомоги на полі бою стрільцями-санітарами, санітарними інструкторами, бойовими та старшими бойовими медиками, зокрема наплічник медичний загальновійськовий санітара та наплічник медичний загальновійськовий санітарного інструктора, які відповідають сучасним вимогам щодо надання медичної допомоги [7].

Проведено наукове обгрунтування медико-технічних вимог до нових зразків військово-медичної техніки, а також забезпечено науковий супровід їх розробки та участь у випробуваннях і дослідній експлуатації, а саме:

броньованих медичних машин: БММ-4С на базі шасі БТР-4; БММ на базі шасі БТР «Saxоn АТ-105»; БММ МТ-ЛБ С; БММ МТ-ЛБу С; БСЕМ на базі БТР-3;

санітарних автомобілів типу A, B, C;

блок-модулів медичного пункту, лазарету, інфекційного ізолятора, для аеромедичної евакуації (МедМ для AME), мобільного медичного модуль-трансформера (ММедМТ) для роботи медичної роти в польових умовах;

операційно-перев'язувального модулю (ОПМ) на базі автомобіля КрАЗ, кабінетів рухомих: хірургічного (на 2 операційних столи), стоматологічного (ПСК), рентгенівського, пересувного комп'ютерного томографу, лабораторії медичної польової;

комплектів табельного медичного майна та майнового комплексу ВМГ.

За досвідом медичного забезпечення 3С України під час АТО/ООС набула подальшого розвитку, відповідно до потреб Медичних сил, система військово-медичної освіти та підготовки медичного персоналу, яку

\section{Висновки}

1. Вивчення, аналіз та узагальнення досвіду медичного забезпечення 3С України під час АТО/OОС стали основою формування сучасної системи медичного забезпечення військ, яка на цьому етапі $\epsilon$ достатньо ефективною 3 огляду на економічні можливості держави.

2. Найбільш важливим здобутком Медичних сил $є$ розроблення і впровадження на державному рівні сучасної функціональноорганізаційної моделі медичного доповнено заново сформованими 205-м Навчальним центром тактичної медицини, 8ми Курсами перепідготовки і підвищення кваліфікації медичного складу, а також збільшено кількість кафедр медицини катастроф та військової медицини у вищих медичних навчальних закладах [7]. Нині система військово-медичної освіти та підготовки має можливості підготовки медичних фахівців необхідного освітньокваліфікаційного рівня за відповідними військово-обліковими спеціальностями, навчально-виховний процес доповнено сучасними організаційними підходами щодо медичного забезпечення військ в умовах бойових дій, а також новими технологіями надання своєчасної та якісної медичної допомоги пораненим, ураженим, травмованим і хворим військовослужбовцям, у тому числі спеціалізованої та високоспеціалізованої.

Наведені теоретичні напрацювання та практичні здобутки стали основою визначення мети, завдань, напрямів, шляхів, етапів і пріоритетів розвитку Медичних сил, конкретних заходів, а також обсягів матеріально-технічного, ресурсного i фінансового забезпечення цього розвитку зі спрямуванням можливостей національної економіки, фінансових ресурсів та міжнародної матеріально-технічної допомоги на розвиток найбільш важливих медичних спроможностей, що стало основою затвердженої Стратегії розвитку Медичних сил Збройних Сил України до 2035 року [18].

Перспективна модель організаційної структури та комплект сил і засобів Медичних сил передбачають досягнення необхідних спроможностей для медичного забезпечення 3C України в імовірних сценаріях їх застосування, у тому числі під час повномасштабної збройної агресії проти України, а також досягнення необхідної взаємосумісності 3 медичними службами держав-членів НАТО.

забезпечення 3С України та інших військових формувань під час дії особливого періоду, надзвичайного стану та інших кризових ситуацій для забезпечення національної безпеки i оборони держави. Розроблена модель системи медичного забезпечення 3С України грунтується на засадах єдиного медичного простору i передбачає функціональне об'єднання потенціалу та зусиль військово-медичних служб і системи цивільної охорони здоров'я, впровадження 
сучасних ефективних організаційних засад медичного забезпечення військ, методів лікування та профілактики захворювань, що відповідають рівню світових досягнень, у тому числі у сфері військової медицини.

3. 3 урахуванням досвіду медичного забезпечення військ під час АTO/OOC а також необхідністю досягнення взаємосумісності 3 медичними службами держав-членів НАТО опрацьовано Стратегію розвитку Медичних сил Збройних Сил України до 2035 року, зокрема перспективну модель, структуру та склад Медичних сил, що будуть спроможними до медичного забезпечення ЗС України в імовірних сценаріях їх застосування, у тому числі під час повномасштабної збройної агресії проти України, а також напрями та шляхи

\section{Література}

1. Указ Президента України від 24 вересня 2015 року № 555/2015 «Про рішення Ради національної безпеки і оборони України від 2 вересня 2015 року «Про нову редакцію Воєнної доктрини України».

2. Указ Президента України від 14 березня 2016 року № 92/2016 «Про рішення Ради національної безпеки і оборони України від 4 березня 2016 року «Про Концепцію розвитку сектору безпеки і оборони України».

3. Указ Президента України від 6 червня 2016 року № 240/2016 «Про рішення Ради національної безпеки і оборони України від 20 травня 2016 року «Про Стратегічний оборонний бюлетень України».

4. Указ Президента України від 14 вересня 2020 року № 392/2020 «Про рішення Ради національної безпеки і оборони України від 14 вересня 2020 року «Про Стратегію національної безпеки України».

5. Білий В.Я. Розвиток системи лікувальноевакуаційних заходів як основи медичного забезпечення військ в особливий період / В.Я. Білий, В.О. Жаховський, В.Г. Лівінський, М.В. Кудренко, І.П. Мельник // Україна. Здоров'я нації (науково-практичний журнал) - К::2016. - Вип. № 3(39) - C. 5-11.

6. Медичне забезпечення Збройних Сил України: стан та погляди на перспективи розвитку. Монографія / Верба А.В., Жаховський В.О., Лівінський В.Г. / Київ: «Видавництво Людмила». 2017. -420 с.

7. Медичне забезпечення Збройних Сил України під час антитерористичної операції та операції Об'єднаних сил на території Луганської та Донецької областей : монографія у 3-х частинах / Хоменко І.П., Лурін I.A., Цимбалюк B.I., Жаховський B.0., Лівінський В.Г., Галушка А.М., Гуменюк К.В., Швець А.В., Іванько О.М. - К.: «Видавництво Людмила», 2020. Ч. I - 386 с., Ч. II - 437 с., Ч. III - 487 с.

8. Постанова Кабінету Міністрів України від 31 жовтня 2018 року ресурсного забезпечення Медичних сил, у тому числі забезпечення сучасними індивідуальними засобами медичного захисту, комплектно-табельним оснащенням, медичними виробами подвійного використання, евакуаційнотранспортними засобами та спеціальною медичною технікою.

4. Спроможні Медичні сили та надійне медичне забезпечення військ в умовах бойових дій $\epsilon$ вагомим внеском у забезпечення національної безпеки та оборони держави через підвищення боєготовності i боєздатності 3С України та інших складових Сил оборони.

№ 910 «Про затвердження Воєнно-медичної доктрини України».

9. Розпорядження Кабінету Міністрів України від 24 травня 2017 року № 352-р «Деякі питання медичного забезпечення військовослужбовців, осіб рядового і начальницького складу та поліцейських, які беруть участь в антитерористичній операції та здійсненні заходів із забезпечення національної безпеки і оборони, відсічі і стримування збройної агресії Російської Федерації у Донецькій та Луганській областях» (зі змінами).

10. Наказ Міністерства оборони України та Міністерства охорони здоров'я України від 07.02.2018 року № 49/180 «Про визначення механізму надання вторинної (спеціалізованої) i третинної (високоспеціалізованої) медичної допомоги військовослужбовцям, які беруть участь в антитерористичній операції та здійсненні заходів із забезпечення національної безпеки і оборони, відсічі і стримування збройної агресії Російської Федерації та/або в умовах запровадження воєнного чи надзвичайного стану» (зі змінами, зареєстрований у Міністерстві юстиції України 28.02.2018 року за № 252/31704).

11. Наказ Генерального штабу Збройних Сил України від 20.12.2017 року № 445 «Про затвердження Доктрини медичного забезпечення Збройних Сил України».

12. Наказ Генерального штабу Збройних Сил України від 09.07.2018 року № 258 «Про затвердження Керівництва з медичної евакуації у Збройних Силах України».

13. Наказ Генерального штабу Збройних Сил України від 11.02.2019 року № 60 «Про затвердження Настанови з медичного забезпечення Збройних Сил України на особливий період».

14. Доктрина «Медичні сили Збройних Сил України», затверджена Головнокомандувачем Збройних Сил України 13 листопада 2020 року.

15. Єдиний медичний простір та військова медицина. Монографія / Жаховський В.О., Лівінський В.Г. ISBN 978-617-7638-00-0 // Київ: 
«Видавництво Людмила». - 2018. - 336 с.

16. Наказ Головнокомандувача Збройних Сил України від 21.09.2020 року № 145/ДСК «Про затвердження Положення про Командування Медичних сил Збройних Сил України».

17. Еволюція системи медичного забезпечення військ під час бойових дій: монографія / Білий В.Я.,

\section{References}

1. «Pro rishennia Rady natsionalnoi bezpeky $i$ oborony Ukrainy vid 2 veresnia 2015 roku «Pro novu redaktsiiu Voiennoi doktryny Ukrainy». (2015). Ukaz Prezydenta Ukrainy vid 24 veresnia 2015 roku № 555/2015. [In Ukrainian].

2. «Pro rishennia Rady natsionalnoi bezpeky $i$ oborony Ukrainy vid 4 bereznia 2016 roku «Pro Kontseptsiiu rozvytku sektoru bezpeky $i$ oborony Ukrainy» (2016). Ukaz Prezydenta Ukrainy vid 14 bereznia 2016 roku № 92/2016. [In Ukrainian].

3. «Pro rishennia Rady natsionalnoi bezpeky $i$ oborony Ukrainy vid 20 travnia 2016 roku «Pro Stratehichnyi oboronnyi biuleten Ukrainy». (2016). Ukaz Prezydenta Ukrainy vid 6 chervnia 2016 roku № 240/2016. [In Ukrainian].

4. "Pro rishennia Rady natsionalnoi bezpeky $i$ oborony Ukrainy vid 14 veresnia 2020 roku «Pro Stratehiiu natsionalnoi bezpeky Ukrainy» (2020). Ukaz Prezydenta Ukrainy vid 14 veresnia 2020 roku № 392/2020. [In Ukrainian].

5. Bilyi, V.Ia., \& Melnyk, I.P. (2016). Rozvytok systemy likuvalno-evakuatsiinykh zakhodiv yak osnovy medychnoho zabezpechennia viisk v osoblyvyi period. Ukraina. Zdorovia natsii (№ 3(39), 5-11). [In Ukrainian].

6. Verba, A.V., \& Livinskyi, V.H. (2017). Medychne zabezpechennia Zbroinykh Syl Ukrainy: stan ta pohliady na perspektyvy rozvytku. Kyiv: «Vydavnytstvo Liudmyla». [In Ukrainian].

7. Khomenko, I.P., Lurin, I.A., \& Ivanko, O.M. (2020). Medychne zabezpechennia Zbroinykh Syl Ukrainy pid chas antyterorystychnoi operatsii ta operatsii Obiednanykh syl na terytorii Luhanskoi ta Donetskoi oblastei. K.: «Vydavnytstvo Liudmyla». [In Ukrainian].

8. «Pro zatverdzhennia Voienno-medychnoi doktryny Ukrainy». (2018). Postanova Kabinetu Ministriv Ukrainy vid 31 zhovtnia 2018 roku № 910. [In Ukrainian].

9. «Deiaki pytannia medychnoho zabezpechennia viiskovosluzhbovtsiv, osib riadovoho i nachalnytskoho skladu ta politseiskykh, yaki berut uchast $v$ antyterorystychnii operatsii ta zdiisnenni zakhodiv iz zabezpechennia natsionalnoi bezpeky i oborony, vidsichi i strymuvannia zbroinoi ahresii Rosiiskoi Federatsii $u$ Donetskii ta Luhanskii oblastiakh» (zi zminamy). (2017). Rozporiadzhennia Kabinetu Ministriv Ukrainy vid 24 travnia 2017 roku № 352-r. [In Ukrainian].
Жаховський В.О., Заруцький Я.Л., Галушка А.М., Лівінський В.Г., Асланян С.А. - К. : «Видавництво Людмила», 2021. - 348 с.

18. Наказ Генерального штабу Збройних Сил України від 12.03.2020 року № 100 «Про затвердження Стратегії розвитку Медичних сил Збройних Сил України до 2035 року».

10. «Pro vyznachennia mekhanizmu nadannia vtorynnoi (spetsializovanoi) $i$ tretynnoi (vysokospetsializovanoi) medychnoi dopomohy viiskovosluzhbovtsiam, yaki berut uchast $v$ antyterorystychnii operatsii ta zdiisnenni zakhodiv iz zabezpechennia natsionalnoi bezpeky i oborony, vidsichi i strymuvannia zbroinoi ahresii Rosiiskoi Federatsii ta/abo $v$ umovakh zaprovadzhennia voiennoho chy nadzvychainoho stanu» (zi zminamy, zareiestrovanyi $u$ Ministerstvi yustytsii Ukrainy 28.02.2018 roku za № 252/31704). (2018). Nakaz Ministerstva oborony Ukrainy ta Ministerstva okhorony zdorovia Ukrainy vid 07.02.2018 roku № 49/180. [In Ukrainian].

11. «Pro zatverdzhennia Doktryny medychnoho zabezpechennia Zbroinykh Syl Ukrainy». (2017). Nakaz Heneralnoho shtabu Zbroinykh Syl Ukrainy vid 20.12.2017 roku № 445. [In Ukrainian].

12. «Pro zatverdzhennia Kerivnytstva $z$ medychnoi evakuatsii u Zbroinykh Sylakh Ukrainy». (2018). Nakaz Heneralnoho shtabu Zbroinykh Syl Ukrainy vid 09.07.2018 roku № 258. [In Ukrainian].

13. «Pro zatverdzhennia Nastanovy z medychnoho zabezpechennia Zbroinykh Syl Ukrainy na osoblyvyi period». (2019). Nakaz Heneralnoho shtabu Zbroinykh Syl Ukrainy vid 11.02.2019 roku № 60. [In Ukrainian].

14. Doktryna «Medychni syly Zbroinykh Syl Ukrainy». (2020). zatverdzhena Holovnokomanduvachem Zbroinykh Syl Ukrainy 13 lystopada 2020 roku. [In Ukrainian].

15. Zhakhovskyi, V.O., Livinskyi, V.H. (2018). Yedynyi medychnyi prostir ta viiskova medytsyna. Monohrafiia. Kyiv: «Vydavnytstvo Liudmyla». [In Ukrainian].

16. «Pro zatverdzhennia Polozhennia pro Komanduvannia Medychnykh syl Zbroinykh Syl Ukrainy». (2020). Nakaz Holovnokomanduvacha Zbroinykh Syl Ukrainy vid 21.09.2020 roku № 145/DSK. [In Ukrainian].

17. Bilyi, V.Ya., Zhakhovskyi, V.O., \& Aslanian S.A. (2021). Evoliutsiia systemy medychnoho zabezpechennia viisk pid chas boiovykh dii. Monohrafiia K. : «Vydavnytstvo Liudmyla». [In Ukrainian].

18. «Pro zatverdzhennia Stratehii rozvytku Medychnykh syl Zbroinykh Syl Ukrainy do 2035 roku». (2020). Nakaz Heneralnoho shtabu Zbroinykh Syl Ukrainy vid 12.03.2020 roku № 100. [In Ukrainian]. 


\title{
МЕДИЦИНСКОЕ ОБЕСПЕЧЕНИЕ ВООРУЖЕННЫХ СИЛ УКРАИНЫ: ОПЫТ, ДОСТИЖЕНИЯ, ПЕРСПЕКТИВЫ
}

\author{
А.Н. Галушка' ${ }^{1}$ В.А. Жаховский ${ }^{2}$, В.Г. Ливинский ${ }^{2}$ \\ ${ }^{1}$ Командование Медицинских сил Вооруженных Сил Украины, г. Киев, Украина \\ 2Украинская военно-медицинская академия, г. Киев, Украина
}

Цель работы: обобщение опыта медицинского обеспечения Вооруженных Сил (ВС) Украины во время осуществления мероприятий по обеспечению национальной безопасности и обороны, отпора и сдерживания вооруженной агрессии Российской Федерации и определение перспектив развития Медицинских сил Вооруженных Сил Украины.

Материалы и методы. Использованы нормативно-правовые акты, руководящие документы, информационно-справочные материалы, монографии и научные статьи в открытых изданиях по медицинскому обеспечению ВС Украины. Объект исследования - система медицинского обеспечения ВС Украины. Предмет исследования - Медицинские силы Вооруженных Сил Украины. Методы исследования: библиографический, аналитический, системного подхода, обобщения, прогностический.

Результаты. Обобщен практический опыт медицинского обеспечения ВС Украины и оказания медицинской помощи раненым, пораженным, травмированным и больным военнослужащим во время осуществления мероприятий по обеспечению национальной безопасности и обороны, отпора и сдерживания вооруженной агрессии Российской Федерации против Украины. Освещены вопросы развития нормативно-правового регулирования функционирования системы здравоохранения военнослужащих и медицинского обеспечения войск. Дана критическая оценка достижений по развитию системы медицинского обеспечения ВС Украины, в частности совершенствованию организационно-штатной структуры медицинских подразделений воинских частей и военно-медицинских учреждений, формированию системы управления Медицинскими силами. Сформулированы принципы единого медицинского пространства государства и определены перспективы развития Медицинских сил ВС Украины.

Выводы. Изучение, анализ и обобщение опыта медицинского обеспечения ВС Украины во время АТО/ООС стали основой формирования современной системы медицинского обеспечения войск. Наиболее важным достижением Медицинских сил является разработка и внедрение на государственном уровне современной функционально-организационной модели медицинского обеспечения ВС Украины и других военных формирований во время действия особого периода, чрезвычайного положения и других кризисных ситуаций для обеспечения национальной безопасности и обороны государства. Способные Медицинские силы и, как результат, надежное медицинское обеспечение войск в условиях боевых действий являются весомым вкладом в обеспечение национальной безопасности и обороны государства, так как способствуют повышению боеготовности и боеспособности ВС Украины и других составляющих Сил обороны.

Ключевые слова: система медищинского обеспечения ВС Украины, медищинская помощь, Медицинские силы Вооруженных Сил Украины.

\section{MEDICAL SUPPORT OF THE ARMED FORCES OF UKRAINE: EXPERIENCE, ACHIEVEMENTS, PROSPECTS}

\section{A. Halushka1, V. Zhahovskiy², V. Livinskiy²}

${ }^{1}$ Medical Forces Command of the Armed Forces of Ukraine, Kyiv, Ukraine ${ }^{2}$ Ukrainian military medical academy, Kyiv, Ukraine

The purpose of the work is generalization of the experience of medical support of the Armed Forces (AF) of Ukraine during the implementation of measures to ensure national security and defense, repulse and deter armed aggression of the Russian Federation and determine the prospects for the development of the Medical Forces of the Armed Forces of Ukraine.

Materials and methods. Regulatory legal acts, guiding documents, information and reference materials, monographs and scientific articles in open publications on medical care of the Armed Forces of Ukraine were used. The object of research is the system of medical support of the Armed Forces of Ukraine. Subject of research - Medical Forces of the Armed Forces of Ukraine. Research methods: bibliographic, analytical, systems approach, generalization, prognostic.

Results. The practical experience of medical support of the Armed Forces of Ukraine and provision of medical care to wounded, injured, traumatized and sick servicemen during the implementation of measures to ensure national security and defense, repulse and deter the armed aggression of the Russian Federation against Ukraine is summarized. The development of normative-legal regulation of the functioning of the health care system of servicemen and medical support of troops is covered. The achievements in the development of the medical support 
system of the Armed Forces of Ukraine, in particular the improvement of the organizational and staffing structure of medical units of military units and military medical institutions, the formation of the Medical Forces management system were critically assessed. The principles of the unified medical space of the state are formulated and the prospects of development of the Medical Forces of the Armed Forces of Ukraine are determined.

Conclusions. The study, analysis and generalization of the experience of medical support of the Armed Forces of Ukraine during the ATO/JFO became the basis for the formation of a modern system of medical support of troops. The most important achievement of the Medical Forces is the development and implementation at the state level of a modern functional and organizational model of medical support of the Armed Forces of Ukraine and other military formations during special periods, emergencies and other crises to ensure national security and defense. Capable Medical Forces and, as a result, reliable medical support of troops in combat are a significant contribution to national security and defense of the state by increasing the combat readiness and combat capability of the Armed Forces of Ukraine and other components of the Defense Forces.

Key words: medical support system of the Armed Forces of Ukraine, medical care, Medical Forces of the Armed Forces of Ukraine.

Конфлікт інтересів: відсутній.

Conflicts of interest: authors have no conflict of interest to declare.

\section{Відомості про авторів:}

Галушка А.М. А,F- полковник медичної служби, доктор медичних наук, професор, начальник штабузаступник командувача Медичних сил Збройних Сил України, м. Київ.

Жаховський В.О. A,B,C,D,E,F - к.н.держ.упр., доц., провідний науковий співробітник Науково-дослідного інституту проблем військової медицини Української військово-медичної академії, м. Київ.

Лівінський В.Г. А,B,C,D,E.F - к.мед.Н., провідний науковий співробітник Науково-дослідного інституту проблем військової медицини Української військово-медичної академії, м. Київ.

$A$ - концепція та дизайн дослідження; $B$ - збір даних; $C$ - аналіз та інтерпретація даних;

$D$ - написання статmi; $E$ - редагування статmi; F- остаточне затвердження статті.

\section{Сведения об авторах:}

Галушка А.Н. - полковник медицинской службы, доктор медицинских наук, профессор, начальник штаба- заместитель командующего Медицинских сил Вооруженных Сил Украины, г. Киев.

Жаховский В.А. - к.н. гос. упр., доц., ведущий научный сотрудник Научно-исследовательского института проблем военной медицины Украинской военно-медицинской академии, г. Киев.

Ливинский В.Г. - к.мед.н., ведущий научный сотрудник Научно-исследовательского института проблем военной медицины Украинской военно-медицинской академии, г. Киев.

\section{Information about authors:}

Halushka A.M. A,F - Col. MS, Doctor of Medical Sciences, Professor, Chief of Staff - Deputy Commander of the Medical Forces of the Armed Forces of Ukraine. https://orcid.org/0000-0003-3530-0946, Kyiv.

Zhakhovsky V.O. A,B,C,D,E,F - candidate of science in public administration, associate professor, Research Institute of Military Medicine of the Ukrainian Military Medical Academy, leading researcher of research department of medical support organization. Email: zhahovskiy-viktor@ukr.net, https://orcid.org/0000-00022665-2766, Kyiv.

Livinskyi V.G. A,B,C,D,E,F - candidate of medical sciences, Research Institute of Military Medicine of the Ukrainian Military Medical Academy, leading researcher of the research department of medical standardization and metrological support. Email: v.livinskiy@gmail.com, https://orcid.org/0000-0002-1102-1128, Kyiv.

$A$ - research concept and design; $B$ - collection and/or assembly of data; $C$ - data analysis and interpretation; $D$ - writing the article; $E$ - critical revision of the article; $F$ - final approval of the article.

Адреса для листування: вул. Московська, 45/1, буд. 33, м. Київ 01015

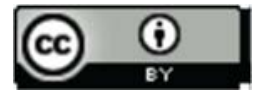

